2. Пилипей Л. П. Моделювання ППФП студентів ВНЗ. Слобожсанський науково-спортивний вісник. Харків, 2009. № 4. C. $26-31$.

3. Редькіна М. А. Особливості індивідуальної рухової активності студентів педагогічних спеціальностей. Гірська школа Українських Kapnam, 2019. № 21. С. $78-81$.

4. Редько Т. М., Франчук О. П., Авдієнко Н. В. Педагогічні умови розвитку рухових якостей студенток вищого навчального закладу. Біомеханічні, педагогічні, психологічні, аспекти фізичного виховання та cnopmy, 2012. № 102. T. 1. C. $310-312$.

DOI https://doi.org/10.30525/978-9934-26-146-6-32

\title{
СУЧАСНІ ТЕНДЕНЦІЇ РОЗВИТКУ КРЕАТИВНОСТІ ІНТЕЛЕКТУАЛЬНО ОБДАРОВАНИХ УЧНІВ У ЗАКЛАДАХ ЗАГАЛЬНОЇ СЕРЕДНЬОЇ ОСВІТИ
}

\author{
Софіюк C. B. \\ учитель украӥнської мови та літератури \\ Житомирська загальноосвітня школа I - III ступенів № 22 імені \\ Василя Михайловича Кавуна \\ м. Житомир, Україна
}

У XXI столітті конкурентоспроможність людини, їі успіх у житті й побудові кар'єри визначається не кількістю накопиченої інформації (чистих знань), а сформованістю компетентностей, що виявляється у здатності успішно соціалізуватися, реалізувати власні цілі, повноцінно жити в умовах сучасного глобалізованого інформаційного світу.

Нині перед українським суспільством загалом та освітянською спільнотою зокрема постали надзвичайно важливі питання пошуку перспективних інноваційних технологій навчання та підходів, які забезпечуватимуть успішне й повноцінне майбутнє, професійний розвиток здобувачів освіти в умовах сьогодення. Так, згідно з Концепцією реалізації державної політики у сфері реформування загальної середньої освіти «Нова українська школа» на період до 2029 року, випускник має бути особистістю, патріотом та інноватором - людиною, яка здатна «змінювати навколишній світ, розвивати економіку, конкурувати на ринку праці й навчатися впродовж життя» [3]. 
Модернізація національної освіти в Україні визначила необхідність розвитку інтелектуального, духовного потенціалу, вихід вітчизняної науки й культури на світовий рівень. Тож виявлення обдарованості (інтелектуальної та творчої), спеціальних здібностей у дітей, їх розвиток і реалізація є однією з актуальних проблем педагогічної теорії та практики.

Обдарованість можна розглядати як високий розвиток здібностей людини, що дає ӥй змогу досягти особливих успіхів у діяльності. Відповідно, загальна обдарованість - високий розвиток інтелектуальних здібностей за умови достатнього обсягу знань. Творча обдарованість високий розвиток творчих здібностей, схильностей і прагнень до творчої роботи. Інтелектуальна обдарованість - це стан індивідуальних психологічних ресурсів (передусім розумових), який забезпечує можливість творчої інтелектуальної діяльності, що пов'язана зі створенням нових ідей, використанням нестандартних підходів до розроблення проблем, чутливістю до ключових, найперспективніших способів пошуку рішень у певній предметній галузі, відкритістю до інновацій тощо.

Робота $з$ обдарованими дітьми в умовах реалізації Концепції НУШ спрямована на реалізацію таких завдань: задовольнити пізнавальні потреби учнів; забезпечити розумовий розвиток школярів; створити позитивне емоційне середовище для стимулювання розвитку особистості; сприяти саморозвитку, самооцінюванню та самореалізації потреб учня; сформувати почуття постійного прагнення до засвоєння нових знань на високому рівні разом із почуттям прекрасного, що сприяє формуванню нестандартного мислення [3].

Термін «креативність» у педагогіці та психології набув поширення на Заході в 60-ті роки XX століття після публікацій робіт Дж. Гілфорда, завдяки яким фактично народжується сучасна психологія творчої обдарованості (психологія креативності) [1]. Більшість учених схиляються до думки, що природа творчості єдина, а тому і здатність до творчості універсальна. Навчившись діяти у сфері мистецтва, техніки чи в інших видах діяльності, людина легко може перенести цей досвід у будь-яку іншу сферу [1].

Проблема розвитку креативності учнів основної школи стосується величезного спектру питань, що пов'язані 3 феноменом розвитку особистості. Креативність і творча діяльність є взаємопов'язаними поняттями. Творча діяльність $є$ фундаментом, передумовою розвитку креативності, метою розвитку особистості. Креативність школяра $\epsilon$ складним синтетичним поняттям, адже іï розвиток пов'язаний із 
створенням нового, оригінального продукту в процесі навчальнотворчої діяльності.

Визначальними особливостями розвитку креативності інтелектуально обдарованих учнів $є$ : вияв зацікавленості в різних сферах навчальної активності; пошук нестандартних рішень типових, на перший погляд, завдань; створення нового, оригінального продукту діяльності; висловлення різноманітних оригінальних ідей та пошук продуктивних шляхів їх застосування.

Креатив може вдихнути нове життя в будь-який учнівський проєкт, показати його досі не розкриті можливості. Більше того, ті, хто здатний мислити нестандартно, можуть винаходити щось абсолютно нове в багатьох сферах життєдіяльності людини. Упровадження в освітній процес сучасних підходів дозволить сформувати в учнів не тільки найважливіші характеристики, які визначають компетентне мислення та формування компетентності дослідника, а й сприяти кращій соціалізації особистості.

Не викликає заперечень той факт, що з метою розвитку творчих здібностей та креативності молодого покоління освітній акцент необхідно переносити з виконання рутинних завдань, запам'ятовування інформації на формування ключових навичок особистості XXI століття: «ефективної співпраці, творчого розв'язання проблем, ухвалювання важливих рішень, керування проєктами, визначення та досягнення цілей, рішучості й наполегливості, спрямування своїх талантів i захоплень на покращення світу та інших» [4].

Одним із важливих принципів реформування освіти в Україні $є$ інтегроване навчання, яке грунтується на комплексному підході. Інтеграція пов'язаних між собою шкільних предметів 3 метою надання учням цілісного розуміння навколишнього світу є одним із пріоритетних напрямів інноваційних освітніх технологій Нової української школи.

32016 року в нашій державі ініційовано поширення STEM-освіти. Але нині, враховуючи об'єктивну потребу створення умов для гармонійного формування науково орієнтованої та креативної особистості, незаперечним фактом виступає те, що впровадження саме STEAM-технологій у закладах загальної середньої освіти ( $\mathrm{S}$ - science, $\mathrm{T}$ - technology, E - engineering, A - Arts, M - mathematics) сприяє формуванню важливих для кожної людини навичок: реагувати на зміни, критично мислити, творчо розвиватися. Саме тому, у відповідь на виклики часу, STEAM-освіта заслуговує особливої уваги. Вдале поєднання розвитку креативності та технічних знань - це спосіб допомогти дітям у майбутньому стати новаторами, цілеспрямованими, творчими й надійними учасниками команди, суспільства, держави [5]. 
Мета STEAM-освіти полягає в цілеспрямованому створенні зв'язків між школою та соціальними практиками, між навчальним процесом $\mathrm{i}$ цілим світом в аспекті розвитку природних здібностей дитини, рівень яких визначатиме іiі успішну самореалізацію як під час навчання, так i поза школою. Учень не просто вчиться генерувати цікаві ідеї, але й відразу втілює їх у життя, навчається планувати свою діяльність, виходячи з поставленого завдання та наявних ресурсів, що обов'язково стане у пригоді в майбутньому [4], [5]. Це свідчить про те, що разом із розвитком науки повинен відбуватися й розвиток мистецтва, адже без рівносильного вивчення науки й мистецьких дисциплін молоде покоління може позбутися навичок креативності. Тому актуальним питанням є створення нових навчальних програм, які передбачають інтеграцію не лише наук та інформаційних технологій, а й мистецького компоненту, упровадження якого дозволить розширити творчий потенціал учнів, сприятиме більш якісній підготовці молоді до успішного працевлаштування та подальшої освіти, яка вимагає більш технічно складних навичок, зокрема вміння мислити творчо.

Отже, прогнозованими результатами роботи з обдарованими учнями з використанням елементів STEAM-освіти $є$ такі вміння: учні володіють різними формами й методиками проведення досліджень; уміють працювати $з$ науково-навчальною літературою; грамотно оформляють власне наукове дослідження; можуть представити наочний матеріал із досліджуваної теми; уміють розподіляти (за необхідності) матеріал на декілька етапів дослідження, добувати інформацію з різних джерел та співпрацювати 3 різними установами; вільно, грамотно, ввічливо спілкуються та відстоюють власні думки, уміють вести дискусію та захищати власні винаходи.

Безперечно, інновації в освіті - це об'єктивний і незворотній процес, зумовлений станом сучасного наукового, технологічного, соціальноекономічного та культурного розвитку людства. Вони сприяють досягненню основної мети сталого розвитку, покращенню якості життя. Відповідно, сучасна шкільна освіта вимагає нової стратегії розвитку, спрямованої на іiї нерозривний зв'язок із життям.

Основною особливістю STEAM-освіти $€$ інтегроване навчання, застосування наукових знань у реальному житті, розвиток креативності як основи втілення в життя нових ідей. Науково-методичні засади створення моделі цього підходу до організації освіти полягають у переході від традиційного навчання до інноваційного шляхом використання методів проєктно орієнтованого навчання. 


\title{
Література:
}

1. Антонова O.С. Сутність поняття креативності: проблеми та пошуки: монографія / за ред. О.А. Дубасенюк. Житомир, 2012. С. 14-41.

2. Колток, Л., Іваник, Н. Упровадження STEM-освіти в освітній процес Нової української школи. Актуальні питання гуманітарних наук: міжвузівський збірник наукових праць молодих вчених Дрогобицького державного педагогічного університету імені Івана Франка. № 27. Т. 3. С. 133-136.

3. Концепція реалізації державної політики у сфері реформування загальної середньої освіти «Нова українська школа» на період до 2029 року. Київ, 2016. URL: https://osvita.ua/legislation/Ser_osv/54258/ (дата звернення: 30.09 .2021$)$.

4. Упровадження STEM-освіти в умовах інтеграції формальної і неформальної освіти обдарованих учнів: методичні рекомендації / Н.I. Поліхун, К.Г. Постова, І.А. Сліпухіна, Г.В. Онопченко, О.В. Онопченко. Київ, 2019. 80 с.

5. STEAM-освіта: інноваційна науково-технічна система навчання. URL: http://ippo.kubg.edu.ua/content/11373 (дата звернення: 28.09.2021).

DOI https://doi.org/10.30525/978-9934-26-146-6-33

\section{USE OF INTERNET RESOURCES IN PROCESS OF TEACHING AND STUDYING MARITIME ENGLISH}

\author{
Tishchenko O. A., Temerbek A. O.
}

Senior Lecturers, Navigation and Ship Handling Chair

Azov Maritime Institute of National University «Odessa Maritime Academy» Mariupol, Ukraine

Modern society makes high demands on students' professional education in mastering foreign languages. Knowledge of a foreign language is necessary to be a competitive person in the market labour. It became not just an object of desire, but an object of life necessity and demand. Hence there are new requirements for the use of new technologies in teaching and the study of the English language. The use of modern information technology (IT) in education is one of the most important and sustainable trends in the development of the modern educational process in professional education and one of the most effective ways in mastering vocabulary in the specialty. IT technologies are the methods of receiving and processing the information. 